\title{
The Importance of Applying the Value Chain Analysis in the Higher Education System
}

\author{
Livia Anastasiu PhD \\ Technical University of Cluj-Napoca, ROMANIA \\ *Corresponding author: Livia Anastasiu
}

\begin{abstract}
Education is the core of any developed society. Higher education graduates have to be prepared to face the challenges in a dynamic global market. Their competences should meet the business demands; therefore the universities should adapt their curricula accordingly. The present paper analyses the activities from the Porter`s Value Chain in order to highlight those that may provide competitive advantage. The author analysed all the activities of the value chain, then adapted them to higher education system and found the activities that leads to competitive advantage. The findings support the idea that, even if universities are service providers in a globalized community, the value chain is a suitable tool for setting the organization`s strategy. By assessing each of the primary activities, the results of the research show that the most important ones are the teaching process (operations), and the graduates' competences (outbound logistics). The departments (infrastructure) and modern technologies that enable communication between the parties (universities, students, and companies) are the main support in achieving the strategic goals. The other activities are also important, but the ones mentioned above are considered to add the most value to the customers, in this case the future students and the business environment, which may decide that their actual employees will be better prepared in higher education institutions by professional teachers.
\end{abstract}

Keywords: strategy, value chain, higher education

\section{Introduction}

The world is in continuous changing in all areas. Globalization is one if the powerful engines that drives the society development in industry, research, or education ${ }^{1}$. Nowadays, no matter the sector of economy, the competitive advantage is the key concept for succeeding in business ${ }^{2}$. In order to have products/services that fulfil the clients` needs, the organizations

\footnotetext{
${ }^{1}$ Awojobi et al., 2014

${ }^{2}$ Brooks et al., 2004
} 
are constantly seeking for core competences which may differentiate them from the competition ${ }^{3}$.

Higher education is a valuable source of well-trained workforce; therefore the graduates KSAs (knowledge, skills and abilities) should meet the market demands ${ }^{4}$. The globalized market in this field allows and encourages the free flow of individuals (students, teachers and researchers), information, and e-learning, as well as diversity ${ }^{5}$. However, the researches found a gap between the competences provided by universities and the demands of the business environment ${ }^{6}$. Some of the employers` critics emphasize the lack of practical skills, as well as the reduced capacity to apply modern technologies and information (Artificial Intelligence, robotics, etc.). That means that the universities find hard to deliver skills and abilities that develop creativity, or innovation. A study focused on the impact of automation in the future shows that most of the respondents think that in 20 years most of the routine and dangerous tasks will be performed by artificial devices. The results are presented in Figure 1.

Figure 1: The use of robotics in economy

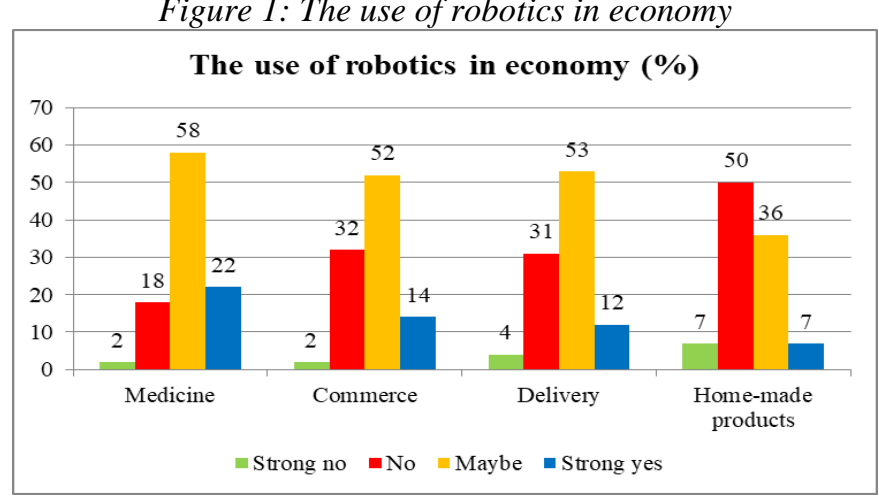

Source: Pew Research Center 2017

The transferable, also known as soft skills, are the most valuable for the hiring companies, as they allow the person to adapt to the organization's strategy, culture and values. Some of them are: goal-oriented, communication, teamwork, decision making, problem solving, creativity, life long learning, or time management ${ }^{7}$, as in Figure 2:

\footnotetext{
${ }^{3}$ Bryson, 2018

${ }^{4}$ Dorri et al., 2012

${ }^{5}$ Suleman, 2016

${ }^{6}$ Mollel et al., 2015

${ }^{7}$ The Global Skills Gap in the $21^{\text {th }}$ Century, 2018
} 
Figure 2: Employers`demand of human capital core skills

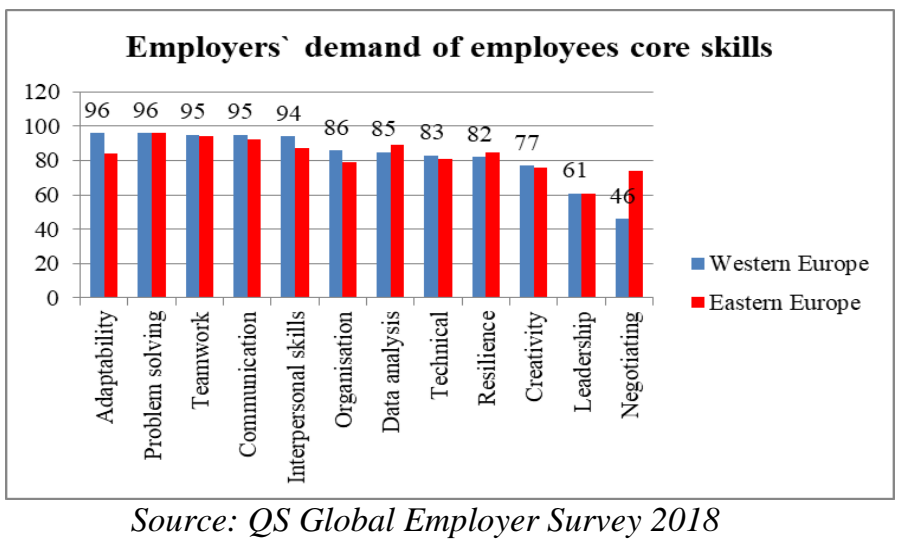

By analysing the findings regarding the required skills, the most important are those related to entrepreneurship, because the technical ones are considered mandatory ${ }^{8}$. However, depending on the university`s profile, most of the disciplines trigger the knowledge, meaning that this may be the main source of gap.

Another important issue is the employers' opinion concerning the balance between the graduates` level of specialization (hard skills) and transferable skills. A survey developed by CareerBuilders in $\mathrm{USA}^{9}$ found that even the knowledge provided by the universities doesn ${ }^{\mathrm{t}} \mathrm{t}$ match the employers`demands.

The challenging environment, especially affected by private schools that are very flexible, e-learning alternatives and the drastically decrease of the European population, are forcing the universities to find ways to attract Generation Z (born after year 2000) and to deliver a mix of KSAs, which are the starting point in hiring professionals. Moreover, the borders for people and jobs are diluted, so youngsters move easily from one country to another, in continuous search for a better future ${ }^{10}$.

In 1985, Michael Porter designed a strategic model to analyse the internal environment of an organization, in order to find the activities that are able to add value to the products/services provided in the competitive market. According to Porter ${ }^{11}$, the value chain is divided in two main activities, each of them having sub-activities: primary activities (inbound logistics, operations, outbound logistics, marketing and sales, service), and support activities (infrastructure, human resources, technology, procurement). By analysing them, the managers may identify those that bring the most value to the clients, so the organization will focus on developing them. At the same time, if some activities are not efficient or/and effective, strategic decisions should be made to improve or outsource them.

Value means the amount of money the customers are willing to pay for the product or service provided by the organization ${ }^{12}$. In order to have competitive advantage against the

\footnotetext{
${ }^{8}$ Rasul et al., 2013

${ }^{9}$ CarieerBuilders USA, 2017

${ }^{10}$ Coelene and Gribble, 2019

${ }^{11}$ Porter, 1985

12 McGee et al., 2010
} 
competitors, the profit margin should exceed the costs ${ }^{13}$. Porter argues that, depending on the organization`s expertise, the value chain may be redesigned, by adding or replacing activities according to the value they offer to the customers ${ }^{14}$.

In case of universities, they are perceived as service providers, so the primary activities cannot be divided like those of manufacturing companies, and the same judgement is made for supporting ones. Some researchers ${ }^{15}$ designed a model of value chain which may be suitable for this area. The main attention is on the teaching process that should provide competences based on the market demands (Figure 3).

Figure 3: Employers`demand of human capital core skills

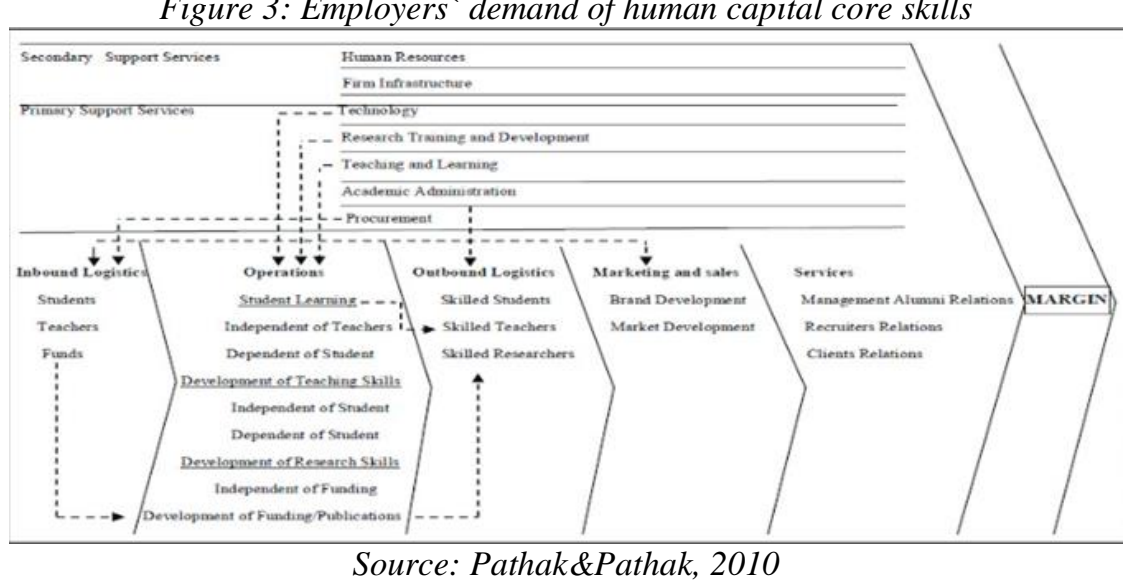

The employability of the graduates is one of the main criteria for people to choose the university. Therefore, the higher education system should adapt the curricula for providing both hard and soft skills. The 2018 Top 10 universities based on the employability rate are ${ }^{16}$ : Harvard University (USA), California Institute of Technology (USA), Massachusetts Institute of Technology (USA), University of Cambridge (UK), Stanford University (USA), Technical University of Munich (Germany), Princeton University (USA), Yale University (USA), The University of Tokyo (Japan), and National University of Singapore (Singapore). As can be seen, six universities come from USA, two from Europe, and two from Asia. This may represent a concern for European universities, as a warning signal for dealing with globalization.

This paper aims to analyse the value chain in the higher education system and find the activities that add the most value to the customer. The model is a generic one, which may be adapted to the university`s specialization.

\section{Research Method}

The value chain is a strategic tool used by managers for identifying the activities that address the most to the customers needs; in this particular case the graduates, the business environment, and the community. The figure below presents the original shape of the value chain (Figure 4).

\footnotetext{
${ }^{13}$ McGee and Sammut, 2014

${ }^{14}$ Makkar et al., 2008

${ }^{15}$ Pathak\&Pathak, 2010

${ }^{16}$ Global University Employability Ranking, 2018
} 
Figure 4: Porter's value chain

\begin{tabular}{|c|c|c|c|}
\hline \multicolumn{5}{|c|}{ Firm`s infrastructure } \\
\hline \multicolumn{3}{|c|}{ Human resources management } \\
\hline \multicolumn{3}{|c|}{ Technology development } \\
\hline \multicolumn{3}{|c|}{ Procurement } \\
\hline $\begin{array}{l}\text { Inbound } \\
\text { Logistics }\end{array}$ & Operations & $\begin{array}{c}\text { Outbound } \\
\text { logistics }\end{array}$ & $\begin{array}{c}\text { Marketing } \\
\text { and sales }\end{array}$ \\
\hline
\end{tabular}

Source: Porter, 1985

As Porter stated, any organization, no matter its specialization, has to plan the future according to the market trends. In his opinion, a value chain is a set of activities developed by a company with the purpose to add value to the customers, in terms of products or services ${ }^{17}$. Consequently, it supplies the resources from the environment, which are transformed in products/services. Next, they are marketed in order to be sold in the environment to customers. Keeping the clients devoted is, maybe, the hardest task, therefore the company provides service and post-warranty. In Porter's model, these are the primary activities. They can be achieved only if they are supported by the cooperation of all departments, including human resources management, the technology used by the company (not the one in the operation process), and the procurement of the inputs. Because each organization has its own way to do business for adding value to the inputs (profit margin), the activities weight different in the value chain.

Table 1 gives examples of activities within a manufacturing organization, according to Porter`s model:

Table 1: Value chain activities for manufacturing organizations

\begin{tabular}{|l|l|l|}
\hline Main Activities & \multicolumn{1}{|c|}{ Type of activity } & \multicolumn{1}{c|}{ Examples } \\
\hline \multirow{5}{*}{ Primary activities } & Inbound logistics & $\begin{array}{l}\text { Quality control, receiving materials, warehousing, } \\
\text { control, supply schedule }\end{array}$ \\
\cline { 2 - 3 } & Operations & $\begin{array}{l}\text { Manufacturing, packaging, production control, quality } \\
\text { control, maintenance }\end{array}$ \\
\cline { 2 - 3 } & Matbound logistics & $\begin{array}{l}\text { Product/service, order handling, dispatch, delivery, } \\
\text { invoicing }\end{array}$ \\
\hline \multirow{5}{*}{ Support activities } & Service & $\begin{array}{l}\text { Customer management, order taking, communication, } \\
\text { pricing, channel management, promotion, sales analysis, } \\
\text { market research }\end{array}$ \\
\cline { 2 - 3 } & Human resources management & $\begin{array}{l}\text { Warranty, repairs, spare parts supply, maintenance, } \\
\text { education and training, upgrades }\end{array}$ \\
\cline { 2 - 3 } & Fechnology development & $\begin{array}{l}\text { General management, planning, legal, accounting, } \\
\text { finance management } \\
\text { planning }\end{array}$ \\
\cline { 2 - 3 } & Procruitment, planning, compensation, training, career \\
\cline { 2 - 3 } & $\begin{array}{l}\text { Process design, engineering, know-how and technology } \\
\text { for each primary activity, R\&D, testing }\end{array}$ \\
\hline
\end{tabular}

${ }^{17}$ Porter and Teisberg, 2006 


\section{Source: Porter 1985}

The world faces a change of paradigm: jobs are grouped around projects, not processes. As digitalization is strongly active in the working environment, people should have competences related to creativity, problem solving, or critical thinking. This is where the universities come in the big picture ${ }^{18}$.

Generation $\mathrm{Z}$ is computer oriented and gets information via Internet. Their problem occurs in filtering the data and understanding the phenomena in their complexity. Therefore, education cannot remain stuck in delivering theoretical knowledge, because huge amount of information is already on social media. Instead, the students should be challenged in solving real problems, not hypothesis.

Universities are urged to adapt to modern trends, because now people, products, services, or knowledge, travel without barriers ${ }^{19},{ }^{20}$. Some authors ${ }^{21}$ argue that the globalized education industry should be based on the following principles: economization (public universities should have their own funds, not only governmental budgets), marketization (the services and people should serve for developing the community, the public health, or the inhabitants prosperity at a global level), commodification (universities should be seen as products/services that add value to consumers, so they should be strategically managed, commercialized and promoted for competitive advantage), and financialization (the graduates' competences should attract the attention of private companies in terms of sponsoring, equipment, or training in modern technologies).

Based on the fact that universities are focused on teaching and research, the activities of the value chain will be shaped in a way to add a consistent value to the consumers using synergy. By analysing the efficiency and effectiveness of each activity, the managers will be able to develop strategies on long term for capturing the best results possible in a changing and competitive environment. They may be assessed in terms of number of students, students and teachers' mobility, amount of funds, level of employability, number of articles, inventions, patents, or other intellectual property.

Universities have to develop their core competences because the business-based approach is getting more and more attention ${ }^{22}$. Modern higher education strategy places the student as in the core of the decision-making, for he/she selects a particular university only if he/she perceives advantages related to employability or personal development ${ }^{23}$.

There is no ideal model for analysing and designing the value chain for the higher education system, because each university has its own profile and specialization; the present research aims to improve the management's strategically approach in long run for developing its competitiveness (Figure 5).

\footnotetext{
${ }^{18}$ Chadwick, 2017

${ }^{19}$ Mundy et al., 2016

${ }^{20}$ Normand, 2016

${ }^{21}$ Parreira do Amaral et al., 2019

22 Emiliani, 2006

${ }^{23}$ Rupa and Pallavi, 2013
} 
Figure 5: Porter's value chain for universities

\begin{tabular}{|c|c|c|c|c|}
\hline \multicolumn{5}{|c|}{ University`s infrastructure: intemational relations, $R \& D$, business cooperation, finance, accomodation } \\
\hline \multicolumn{5}{|c|}{ Human resources management: recruitment, selection, compensation, career development } \\
\hline \multicolumn{5}{|c|}{ Technology development: mobile apps, social media, intranet } \\
\hline \multicolumn{5}{|c|}{ Procurement: cost-based, suppliers, professional selection } \\
\hline $\begin{array}{l}\text { Inbound logistics } \\
\text { - Students; } \\
\text { - Teachers; } \\
\text { - Funds. }\end{array}$ & $\begin{array}{l}\text { - Operations } \\
\text { - Teaching; } \\
\text { - Research; } \\
\text { - Cooperation; } \\
\text { - Projects. }\end{array}$ & $\begin{array}{l}\text { Outbound logistics } \\
\text { - Graduates; } \\
\text { - Teachers; } \\
\text { - Researchers. }\end{array}$ & $\begin{array}{l}\text { Marketing } \\
\text { - Brand; } \\
\text { - Community; } \\
\text { - Promotion. }\end{array}$ & $\begin{array}{l}\text { Post education } \\
\text { - Alumni; } \\
\text { - Consultancy; } \\
\text { - Innovation. }\end{array}$ \\
\hline
\end{tabular}

Source: Author

The main focus is to find those activities that allow the universities to become leaders in the area, a strong globalized one. The universities are competing all over the world, so they have to differentiate in order to attract top students ${ }^{24}$. All the strategies adopted are meant to stay in the business ${ }^{25}$, because the universities' results should match the needs of the end users, in this case the labour market.

\subsection{Primary activities}

All these activities follow the educational flow. The students/teachers are recruited, trained and they are well prepared for the competitive workforce market. For succeeding, universities have to develop marketing strategies, and to provide services for attracting future candidates. A major problem, especially for public institution, is the lack of flexibility, in terms of velocity to adapt to the market changes.

\subsubsection{Inbound logistics}

The inputs are the people who want to develop their KSAs and choose a particular university for achieving them. They may be youngsters coming from high schools, as well as employees wanting to improve their knowledge. This is an important category, because companies select educated people for jobs, especially if they need specific competences. Other categories are the researchers and teachers. Based on these argues, the recruitment process in essential.

Studies show that the education industry will grow in the next years. In terms of money, only in USA it will reach 2.600 billion \$ in 2026, compared with 1.350 billion \$ in 2017 (93\% growth $)^{26}$.

Another aspect related to inputs is the possibility to attract external funds that may come from non-reimbursable sources, or other sources. They will stand as base for acquiring equipment, or modern technologies which will facilitate professional teaching and research.

\subsubsection{Operations}

This activity is related to the teaching methods which should be computer-based and interactive. The teachers are seen today as facilitators to students for finding answers by their

\footnotetext{
${ }^{24}$ Kotabe and Kothari, 2016

${ }^{25}$ Mcdonald, 2016

${ }^{26}$ Zion Market Research, 2018
} 
own capabilities. Dictated courses are history. Now students are facing real situation which they have to solve by the help of teachers.

E-learning, as well as blended learning are other ways to deliver the message, each of them with pros and cons. On-line courses are solutions for busy students that cannot participate at fixed locations and timeline. However, the lack of interaction may harm the understanding of the courses`content.

The main tasks are: the teaching process for students and researchers; the life long training of the teachers for updating their knowledge; and the cooperation with the business environment for gaining visibility in the community.

Another important issue is related to research: all universities are focused on innovation; therefore they enrol researchers and develop doctoral stages for discovering new products or materials that will be delivered in the business market. The results of research may be quantified in number of articles, citations, doctoral thesis, patents, or other intellectual property.

\subsubsection{Outbound logistics}

The outputs of the teaching process may be divided in three groups: the graduates who will be prepared for the workforce market; the researchers who may continue with doctoral studies, or enrol in research institutions; and teachers who will be able to spread the knowledge around the community and all over the world. The target group`s message is also a way to promote the university or, contrary, to discourage future candidates to apply, if they don `t feel the added value.

The outputs of this activity may be: number of graduates, number of articles published in high impact volumes, number of patents, number of students and teachers mobility, employability rate, and others.

\subsubsection{Marketing and sales}

The three parties that are contributing to the educational process should be gathered at the same table, and share information and findings. All can benefit from this initiative: students may be trained more effective and learn from others; teachers may update their curricula based on the business market's interests in KSAs; and companies may use the results of studies and research in their specific area. Thus, new ideas and best practices may be spread around the business and academic community.

Online courses are another way to promote the university. They are widely accessed in the academic and business environment. Only in 2018, 20 million people enrolled in MOOCs (Massive Online Open Courses). The most accessed providers are: Coursera (37 million), edX (18 million), XuetangX (14 million), and Udacity (10 million $)^{27}$.

\subsubsection{Service}

In case of universities, it refers to post-education services. Even if universities are knowledge providers, their visibility in the business environment is a key factor for attracting future students, teachers, and researchers.

The R\&D activity may bring products or services for the global environment. The companies may pay for the inventions, patterns or other intellectual property, which may be a major

${ }^{27}$ MOOCs, 2018 
source of financing future projects. Moreover, this may be a successful way to attract pay-fee students.

\subsection{Supporting activities}

These activities are performed by people from university`s departments and help the fulfilment of primary activities.

\subsubsection{University`s infrastructure}

Universities have to act global. Their achievements should be recognized internationally. Erasmus programs allow the mobility of people (students, teachers, researchers) who are the main messengers of the academic results.

One of the most important parts of the university`s infrastructure is the research and development department. The work of researchers results in scientific articles, inventions, patents, new materials and products.

Another important issue is the students' accommodation. The campus should provide libraries, facilities, modern technologies and gadgets, cleaning services, and others.

\subsubsection{Human resources management}

People are the most important asset of an organization. Their performances have an impact on the prestige, in a good or bad way. Therefore, teachers and administrative stuff have to be selected on proper criteria, trained and rewarded based on results, because otherwise they will leave the organization in search for equity. These are the HR responsibilities.

\subsubsection{Technology development}

The technologies refer to equipment and softs that support the R\&D activity (research laboratories, and computer softs used to organize, perform and coordinate the activities of all the departments. Communication is essential in the organizational structure, both horizontally and vertically.

\subsubsection{Procurement}

All the inputs have to be purchased from external suppliers. The products/services provided should meet the university`s goals: modern teaching methods, equipment for research laboratories, computer-based information systems, or efficient cooperation between departments.

The outputs of the strategically analyse of the value chain in the particular case of universities should be: updated information (provided by teachers and researchers), innovation (articles, citations, patents), and visibility (brand teachers, researchers and graduates). These results may represent base for recruitment, funds from business environment, and the development of the community.

\section{Conclusion}

Universities are service providers in an international changing environment. The main activities concern the delivery of courses and applications, and the practical results of research, that may be used by companies to improve their economic outputs, enabling the development of the community. 


\section{International Conference on Applied Research in BUSINESS, MANAGEMENT and ECONOMICS}

The competences of the higher education graduates should be evaluated global, since they may apply for jobs internationally. This is a permanent concern of policy makers which aim to design a framework regarding the needed skills of students for a competitive workforce market. The European Commission (2010) set an "Agenda for New Skills and Jobs" which allow universities and companies to access funds to develop skills based on future jobs, mainly those dealing with robotization, or Artificial Intelligence.

Porter's approach on organizations is a resource-based one, where the main accent is pointed on availability of resources and core competences: they have to be identified, and then the company will develop strategies to use them and deliver that products/services that add the most value to customers, in order to gain competitive advantage.

There are argues on the utility of Porter`s value chain in higher education, since it was designed mainly for manufacturing. However, the principle is the same: the net value is created if the difference between the benefits and costs is positive (Customer delivered value), in this case the business market.

Based on the analyse of the value chain, the activities that capture the most added value from customers are: recruitment of students, researchers and teachers (inbound logistics), the content and utility of knowledge delivered connected with the results of the research and projects (operations), and the constant connection with the external environment (post education).

These primary activities should be supported by the top management of the universities with actions focused on international relationships, the modern technologies that allow the users (students, teachers and researchers) to access and filter the data in a professional way, and the accommodations provided to students.

By applying the value chain model in the higher education system, the top management will be able to develop strategies that will allow the universities to gain competitive advantage on long term.

However, the universities should consider digitalization as one of their strong enemies ${ }^{28}$, because E-learning is getting more and more attention. It`s hard to compete with long distance methods of teaching, unless they will find ways to attract face to face participation, by delivering information and connect them to practice.

\section{References}

[1] Awojobi, O.N., Tetteh, J. and Awojobi, A. (2014). "The effect of globalization on workers 'rights in the global south: Evidence from Nigeria". International Journal of Economics, Commerce and Management, vol. 2(11), pp. 1-9.

[2] Brooks, I., Weatherston, J. and Wilkinson, G. (2004). The International Business Environment, $1^{\text {st }}$ ed. Essex, U.K.: Prentice Hall.

[3] Bryson, J.M. (2018). Strategic Planning for Public and Non-profit Organizations, $5^{\text {th }}$ ed. New Jersey, Canada: Wiley.

[4] Chadwick, C. (2017). "Towards a more comprehensive model of firms' human capital rents". Academy of Management Review, vol. 42(3), pp. 499-519.

${ }^{28}$ Davidenkoff, 2014 
[5] Coelen, R. and Gribble, C. (2019). Internationalization and Employability in Higher Education, $1^{\text {st }}$ ed. New York, USA: Routledge.

[6] Davidenkoff, E. (2014). Le Tsunami Numérique. Éducation: Tout Va Changer! Êtes Vous Prêts?. Éditions Stock.

[7] Dorri, M., Yarmohammadian, M.H. and Nadi, M.A. (2012). "A review on value chain in higher education". Elsevier Procedia - Social and Behavioural Sciences, vol. 46, pp. 3842-3846.

[8] Emiliani, M.L. (2006). "Improving management education". Quality Assurance in Education, vol. 14(4), pp. 363-384.

Global

University

Employability

(2018).

Available: https://www.timeshighereducation.com/student/best-universities/best-universitiesgraduate-jobs-global-university-employability-ranking

[10] Kotabe, M. and Kothari, T. (2016). „Emerging market multinational companies evolutionary paths to building a competitive advantage from emerging markets to developed countries“. Journal of World Business, vol. 51(5), pp. 729-743.

[11] Makkar, U., Gabriel, E. and Tripathi, S.K. (2008). "Value chain for higher education sector case studies of India and Tanzania". Journal of Services Research, Special Issue, pp. 183-200.

[12] Mcdonald, M. (2016). "Strategic marketing planning. Theory and practice". Journal of Marketing Management, vol. 12(1), pp. 4-27.

[13] McGee, J., Wilson, D., and Thomas, D. (2010). Strategy: Analysis and Practice, $2^{\text {nd }}$ ed. McGraw-Hill, Maidenhead.

[14] McGee, J. and Sammut-Bonnici, T. (2014). Wiley Encyclopaedia of Management. Vol. 12. Strategic Management, $3^{\text {rd }}$ ed. London, UK: Wiley.

[15] Mollel, E.R., Mulongo, L.S. and Maket, L. (2015). "Workforce diversity management and global organizational growth in the $21^{\text {th }}$ century". Journal of Scientific Research and Studies, vol. 2(7), pp. 164-175.

[16] By the Numbers: MOOCs in 2018. Available: https://www.classcentral.com/report/mooc-stats-2018/

[17] Pathak, V. and Pathak, K. (2010). "Reconfiguring the higher education value chain". Management and Education, vol. 24(4), pp. 166-171.

[18] Porter, M.E. (1985). Competitive Advantage. Creating and Sustaining Superior Performance, $2^{\text {nd }}$ ed. New York, USA: The Free Press.

[19] Porter, M.E. and Teisberg, E.O. (2006). Redefining Health Care: Creating ValueBased Competition on Results. Boston, USA: Harvard Business School Press.

[20] Rasul, M., Rauf, R. and Mansor, A. (2013). "Employability skills indicator as perceived by manufacturing employers”. Asian Social Science, vol. 9(8), pp. 42-46.

[21] Rupa, R. and Pallavi, R. (2013). "Service value chain models in higher education". International Journal of Emerging in Management and Technology, vol. 2(7), pp. 1-6. 
[22] Suleman, F. (2016). "Employability skills for higher education graduates: little consensus on a much-discussed subject”. Elsevier Procedia - Social and Behavioural Sciences, vol. 228, pp. 169-174.

[23] The Global Skills Gap in the 21 th Century (2018). Available: http://www.apa.org/helpcenter/road.resilience.aspx

[24] CareerBuilders (2017). Near Three in Four Employers Affected by a Bad Hire. Available: $\quad$ http://press.careerbuilder.com/2017-12-07-Nearly-Three-in-FourEmployers-Affected-by-a-Bad-Hire-According-to-a-Recent-CareerBuilder-Survey

[25] Mundy, K., Green, A., Lingard B. and Verger A. (2016). The Handbook of Global Education Policy, $1^{\text {st }}$ ed. Chichester, UK: Wiley.

[26] Normand, R. (2016). "The Changing Epistemic Governance of European Education", Springer Educational Governance Research, vol. 3, pp. 23-62.

[27] Pareira do Amaral, M., Steiner-Khamsi, G. and Thompson, C. (2019). Researching the Global Education Industry. Commodification, the Market and Business Involvement, $1^{\text {st }}$ ed. Cham, Switzerland: Palgrave Macmillan.

[28] Zion Market Research 2018. Available: https://www.globenewswire.com/newsrelease/2018/04/09/1466926/0/en/U-S-Education-Market-Will-Reach-USD-2-040billion-by-2026-Zion-Market-Research.html 